\title{
Correlation between Knowledge of WLHA about PMTCT with Motivation Planning Pregnancy in Peer Suport Group at Bandung City
}

\author{
Kusila Devia Rahayu' ${ }^{1 *}$, Yanti Herawati², and Gina N Padilah ${ }^{3}$ \\ 1,3Program Studi Bachelor of Nursing, Institute Health Science Dharma Husada Bandung, Indonesia \\ 2Program Studi Diploma of Midwifery, Institute Health Science Dharma Husada Bandung, Indonesia \\ *Correspondence: kusila.rahayu@gmail.com
}

Type of the Paper (Article)

Received: September 1, 2019; Accepted: October 1, 2019; Published: October 30, 2019 https://doi.org/10.29253/achnr.2019.1637

\begin{abstract}
The increasing number of pregnancies of women living with HIV/ AIDS (WLHA) and the number of children living with HIV/AIDS as a result of being infected from mother to child during pregnancy, childbirth and breastfeeding made researchers feel the need to conduct this study. This study aims to determine the relationship between the knowledge of WLHA about Preventions Mother to Child Transmission (PMTCT) with the motivation to plan pregnancy in peer support groups in Bandung. This quantitative study was designed using a cross sectional approach to 80 respondents. Data collection was carried out using a knowledge questionnaire about PMTCT and a child bearing questionnaire which was translated. Both instruments passed the validity and reliability tests before use. Data collection was carried out using purposive sampling method. The research data were analyzed using Chi-Square test. The results showed that $82.5 \%$ of respondents have a good PMTCT knowledge and $61.3 \%$ of respondents have a low motivation to plan pregnancy. The results of the bivariate analysis showed p-value $0.03(\mathrm{P}<0.05)$. This indicated that the knowledge of WLHA about PMTCT was significantly related to the motivation to plan pregnancy in the Peer Support Group in Bandung City. Health workers need to improve their ability to collaborate with peer support groups as a means of providing education so that WLHA knowledge about PMTCT can be increased so that the number of WLHA pregnancies and the number of children with HIV/AIDS does not increase.
\end{abstract}

Keywords: women living with HIV/AIDS; children living with HIV/AIDS; prevention mother to child transmition; peer support groups

\section{Introduction}

WHO (2019) explains that the Human Immunodeficiency Virus (HIV) is a virus that attacks and destroys the human immune system, causing immune system paralysis and ultimately making HIVinfected people susceptible to other infections and increasing the risk of cancer. When HIV has impaired the function of immune cells, gradually the infected individual will experience immune deficiency. The advanced stage of HIV infection is AIDS (Acquired Immunodeficiency Syndrome).

HIV and AIDS has become a global emergency problem. WHO (2018) explains that globally it is known that 35 million people are living with HIV and 19 million people do not know their status. WHO 
(2018) also explains that the prevalence of HIV/AIDS in Asia is 37\% with the highest prevalence in China, India, and Indonesia. Indonesia as the third country with the largest number of HIV/AIDS in Asia Pacific, has been working hard to deal with this pandemic and has actively participated in the global handling of HIV/AIDS by being involved in the formation and implementation of programs to eradicate global problems through the millennium Development Goals (MDGs) $2002-2015$ and Sustainable Development Goals (SDG's) 2015-2030.

Transmission of HIV/AIDS can occur through various modes of transmission, including through sexual contact with an infected person, contact with blood from an infected person, sharing needles and transmission from mother to child (WHO, 2019). Prevention of mother to child transmission (PMTCT) is an effort to break the chain of HIV transmission from mother to child, because more than $90 \%$ of HIV positive babies are infected by HIV positive mothers during pregnancy and childbirth or breastfeeding (Cunningham, 2010).

Regarding the number of children suffering from HIV/AIDS, UNAIDS (2017) reported that 180,000 children aged 0-14 years were infected with the HIV virus and 110,000 children died due to AIDS-related illness. UNAIDS (2017) also reports that the prevalence of pregnancy with HIV / AIDS increases among women of childbearing age 20-29 years. This is a problem that needs to be addressed immediately considering the high risk of HIV infection on the health of pregnant women and the fetus in their womb.

The Ministry of Health (2018) explained that the prevalence of HIV/AIDS infection cases in Indonesia has increased every year. In 2018, it was known that the number of HIV sufferers was 291,129 people and the number of AIDS sufferers was 106,965 people and West Java was the third province that contributed the most to the number of HIV/AIDS in Indonesia with 30,624 people. Bandung City Health Office (2018) explains that Bandung is the city in West Java with the highest number of PLWHA. The number of HIV sufferers in Bandung is 2,709 and the number of AIDS sufferers is 2,116. Bandung City Health Office (2018) also reported that the characteristics of PLHIV in Bandung were 76\% male, 24\% female and 10\% housewife. This means that there are more male PLWHA than female PLHIV and many women PLWHA who come from the housewives group. This is a sign of the need to pay more attention to efforts to prevent infectious diseases from mother to child. Related to this, Fitriana (2015) explains that to increase the coverage of PMTCT-related education, a peer support group was formed as a forum for PLWHA to share health information among sufferers.

Isni, Shaluhiyah and Cahyo (2017) explained that factors related to the behavior of HIV mothers in preventing HIV/AIDS transmission from mother to baby are the age of the baby, when HIV status is known, time to start taking ARVs, participation in PMTCT, time to start following PMTCT, and knowledge. Notoatmodjo (2014) defines knowledge as a result of human sensing or the result of someone knowing an object through their five senses. Most of the knowledge is obtained through the senses of sight and hearing. There are several factors that can affect individual knowledge, namely factors of education, occupation, age, culture or environment and information.

Nursalam (2016) defines motivation as a human characteristic that contributes to a person's level of commitment. This includes the factors that cause, transmit and sustain human behavior in a particular direction of determination. Motivation can also be defined as anything that encourages someone to do something. (Nursalam, 2016). Based on various definitions of motivation, there are three things that are important in terms of motivation, namely the relationship between needs, drives and goals. The need will arise if a person feels something that is not good physiologically or psychologically. Encouragement is a direction to meet needs, while goals are the end of a motivation cycle. This cycle is the basic cycle of motivation. There are other factors that play a role in this cycle, namely cognitive factors. Cognitive itself is a mental process such as thinking, memory and perception. With the role of cognitive factors, the driving state can be triggered by thoughts or memories (Nursalam, 2016).

Kemenkes (2015) states that HIV positive women who want to become pregnant must plan their pregnancy and meet the eligibility requirements for pregnancy. The health condition of HIV positive women was generally stated to be good, namely based on the results of anamnesis, physical examination and verification of the results of laboratory tests. Women with HIV were in HIV stage 1 or 2 with a CD4 count $>350$ cells / mm3 and a viral load $\leq 1000$ copies / $\mathrm{mL}$ (undetectable viral load). In addition, there were no signs / symptoms of opportunistic infection and had been following regular ARV therapy for at least 6 months. If one of the conditions has not been met, it is advisable to postpone pregnancy. The current situation is there are many women with HIV/AIDS experience pregnancies without prior 
planning and conduct their pregnancies without consulting PMTCT officers. This provides an opportunity for the increasing prevalence of new-borns with HIV/ AIDS due to infection from their mothers. This phenomenon shows the importance of better efforts to increase the knowledge of WLHA about PMTCT.

Education on prevention of transmission of HIV/AIDS from mother to child has been intensively carried out by health workers in Indonesia, however the prevalence of pregnancy among women living with HIV/AIDS and the prevalence of children living with HIV/AIDS who are infected from mother to child is increasing every year. West Java is a province in the top ten with the largest number of people living with HIV/AIDS in Indonesia. Bandung City is the capital city of West Java province which has a referral hospital to serve people living with HIV/AIDS in West Java Province. Fitriana (2015) noted an increase in the findings of new cases of HIV/AIDS so that the total number of people living with HIV/AIDS in the city of Bandung in January 2015 was 1253 patients with the percentage of male with HIV/AIDS as much as $64.22 \%$ and female with HIV/AIDS as much as $35.78 \% .83 .14 \%$ people living with HIV/AIDS were aged 20-39 years and $16.16 \%$ of the people living with HIV/AIDS were children, adolescents and > 40 years. This phenomenon makes researchers feel the need to conduct research on whether there is a relationship between the knowledge of women living with HIV about prevention of mother-to-child disease transmission (PMTCT) and the motivation to plan pregnancy in peer support groups in Bandung.

\section{Methods}

This research is designed quantitatively. The population of this study were women living with HIV in the city of Bandung. The sample of this study were women living with HIV who were members of peer support groups for women living with HIV in the city of Bandung. Sampling was done by purposive sampling, with a total sample of 80 respondents. The inclusion criteria for this study were women living with HIV who were of reproductive age, married or unmarried, domiciled in Bandung, willing to be respondents, able to read and write. The exclusion criteria for this study were women living with HIV who were not members of peer support groups in Bandung. This study uses three research instruments, namely the demographic characteristics questionnaire, the PMTCT knowledge questionnaire and the childbearing questionnaire (Sowwel, 1999). The PMTCT Knowledge Questionnaire was designed by researchers referring to the PMTCT Ministry of Health Indonesian guidebook (2015) and the childbearing questionnaire has a validity value of 0.08 in previous studies and follows the translation process first. Meanwhile, the motivation variable of PLWHA to plan pregnancy, the researcher adopted a research instrument conducted by Sowell (1999). This questionnaire has been tested for validity by previous researchers with an alpha value of 0.84 . All questionnaires were tested for validity and reliability before being used. The study was conducted using research ethics: respect for human dignity, respect the privacy and confidentiality, fairness and inclusiveness. The research was analyzed by univariate and bivariate. Bivariate analysis was performed using the Chi Square Test.

\section{Finding}

Based on Table 1, it is known that based on the characteristics, the respondents in this study were $57.5 \%$ aged $36-45$ years, on the last education characteristics $66.3 \%$ had a high school education, on the occupation characteristics $77.5 \%$ were housewives, on the characteristics of the marital status $57.5 \%$ were married, on the characteristics of the number of children $98.7 \%$ had children, on the characteristics of long times diagnosed HIV 96.3\% diagnosed >6 months and on the long-time taking ARV 96.3\% had consumed ARV> 6 months. 
Table 1. Frequency distribution of respondent characteristics: age, currant education, occupation, marital status, number children, long diagnosed with HIV, length of time taking ARVs (n: 80).

\begin{tabular}{|c|c|c|}
\hline Respondent characteristics & $\mathbf{F}$ & Presentation (\%) \\
\hline \multicolumn{3}{|l|}{ Age } \\
\hline$-15-25$ year & 2 & 2.5 \\
\hline$-26-35$ year & 32 & 40.0 \\
\hline$-36-45$ year & 46 & 57.5 \\
\hline \multicolumn{3}{|l|}{ Currant Education } \\
\hline - primary school & 2 & 2.5 \\
\hline - Junior high school & 13 & 16.3 \\
\hline - Senior High School & 53 & 66.3 \\
\hline - College & 12 & 15.0 \\
\hline \multicolumn{3}{|l|}{ Occupation } \\
\hline - housewife & 62 & 77.5 \\
\hline -employees & 18 & 22.5 \\
\hline \multicolumn{3}{|l|}{ Marital Status } \\
\hline -Single & 0 & 0 \\
\hline -Divorce & 34 & 42.5 \\
\hline - married & 46 & 57.5 \\
\hline \multicolumn{3}{|l|}{ Number of Children } \\
\hline - Don't have children yet & 1 & 1.3 \\
\hline - already have children & 79 & 98.7 \\
\hline \multicolumn{3}{|l|}{ Long been diagnosed HIV } \\
\hline$-<6$ month & 3 & 3.7 \\
\hline - > 6 month & 77 & 96.3 \\
\hline \multicolumn{3}{|l|}{ Long-time taking ARV } \\
\hline$-<6$ month & 3 & 3.7 \\
\hline$->6$ month & 77 & 96.3 \\
\hline Number & 80 & 100 \\
\hline
\end{tabular}

Table 2. Frequency distribution of respondents' knowledge (n: 80).

\begin{tabular}{lcc}
\hline Knowledge level & F & Presentation (\%) \\
\hline Good Knowledge & 66 & 82.5 \\
Enough Knowledge & 4 & 5.0 \\
Lack of Knowledge & 10 & 12.5 \\
\hline Number & 80 & 100 \\
\hline
\end{tabular}

Based on Table 2, it is known that $82.5 \%$ of respondents have a good knowledge of PMTCT.

Table 3. Frequency distribution of respondents' planning for pregnancy motivation (n: 80).

\begin{tabular}{lcc}
\hline Motivation & F & Presentation (\%) \\
\hline Strong motivation & 31 & 38.8 \\
Weak motivation & 49 & 61.2 \\
\hline Number & 80 & 100 \\
\hline
\end{tabular}

Based on Table 3, it is known that $61.2 \%$ of respondents have a weak motivation to plan a pregnancy.

Table 4. Relationship between respondent's PMTCT knowledge and motivation to plan pregnancy (n: 80).

\begin{tabular}{|c|c|c|c|c|c|c|c|}
\hline \multirow{3}{*}{ Knowledge about PMTCT } & \multicolumn{4}{|c|}{ Motivation for Planning Pregnancy } & \multirow{2}{*}{\multicolumn{2}{|c|}{ Total }} & \multirow{3}{*}{ P-Value } \\
\hline & \multicolumn{2}{|c|}{ strong motivation } & \multicolumn{2}{|c|}{ weak motivation } & & & \\
\hline & $\mathbf{n}$ & $\%$ & $\mathbf{n}$ & $\%$ & $\mathbf{n}$ & $\%$ & \\
\hline Good Knowledges & 22 & 27.5 & 44 & 55.0 & 66 & 82.5 & \multirow{4}{*}{0.03} \\
\hline Enough Knowledges & 3 & 3.8 & 1 & 1.3 & 4 & 5.0 & \\
\hline Lack of Knowledges & 6 & 7.5 & 4 & 5.0 & 10 & 12.5 & \\
\hline Number & 31 & 38.8 & 49 & 61.3 & 80 & 100 & \\
\hline
\end{tabular}


Based on Table 4, it is known that respondents who have good knowledge of PMTCT 55.0\% experience weak motivation to plan pregnancy with a p-value of $0.03(<0.05)$. So that the results of the bivariate analysis showed that $\mathrm{HO}$ was rejected or there was a significant relationship between the knowledge of women living with HIV about PMTCT with the motivation to plan pregnancy in peer support groups in Bandung City.

\section{Discussion}

In this study, the characteristics of the respondents were not analyzed cross-sectional with the variable of respondents' motivation. Respondent characteristics are used to identify the characteristics of respondents in peer support groups in Bandung City. The results of the research on the characteristics of the respondents indicated that the respondents who joined the peer support group were limited to the upper-level demographic group. It is known that women living with HIV /AIDS who are members of the HIV/AIDS peer support group in Bandung City are known to have mostly 35-45 years of age, have high education, work as housewives, receive a diagnosis of HIV/AIDS> 6 months, consume ARV> 6 months. The results of this study have similarities with the results of Rahayu's research (2017) which was also conducted in Bandung. Rahayu (2017) explains that the characteristics of PLHIV couples in Bandung City who use dual protection contraception are 35-45 years old, highly educated, diagnosed with HIV / AIDS> 6 months, consuming ARV> 6 months. Rahayu's (2017) research does not explain peer support groups, however, it is known that Rahayu's (2017) findings have similarities with the findings in this study.

In addition, Rahayu (2017) also explained that the knowledge of PLWHA couples about the use of dual protection contraception has a meaningful relationship with the use of dual protection contraception in PLWHA partners. This shows that the PLWHA couples have been exposed to information about pregnancy regulation in HIV/AIDS sufferers and the prevention of HIV/AIDS transmission, but the fact that the prevalence of pregnancy among women living with HIV/AIDS is increasing and the prevalence of HIV/AIDS children is increasing is undeniable.

The results of research on knowledge of PMTCT found that respondents in peer support groups in Bandung City mostly have good knowledge of PMTCT, as well as the results of research on motivation to plan pregnancy it is known that respondents in peer support groups in Bandung City have weak motivation to plan pregnancy. In bivariate terms, the relationship between PMTCT knowledge and motivation to plan pregnancy in the peer support group was found to have a p-value of $0.03(<0.05)$. This means that the null hypothesis is rejected and the research hypothesis is accepted, namely that the knowledge of women living with HIV about PMTCT in peer support groups has a significant relationship with motivation to plan pregnancy.

The results of this study are in line with Nursalam's (2016) motivation cycle which states that the element of motivation consisting of the need for encouragement and goals is influenced by knowledge factors. Where needs will arise if individuals feel there is an imbalance between what is owned and what is expected. Encouragement is a mental strength that is oriented towards meeting expectations or achieving a goal. This goal-oriented drive is the essence of motivation. Motivation is a circular cycle, where the motivation that arises will trigger behavior that is focused on a goal, and finally after the goal is achieved, the motivation will stop.

One of the ways that can encourage someone to behave healthily is by increasing knowledge about health. Knowledge is also intended to provide correct information to an inaccurate and non-conducive understanding that can worsen a person's health. Knowledge is needed as support in fostering selfconfidence and attitudes and behavior every day, so it can be said that knowledge is an important domain for shaping one's actions. So that someone who has good knowledge about PMTCT will behave well to prevent HIV transmission to children, one of which is not planning to have children.

This research is in line with research conducted by Pratiwi (2019) and Sunirah (2017), which state that there is a significant relationship between knowledge and motivation. Where motivation will be implemented properly if someone knows the benefits that can be taken so that adequate knowledge is needed about the problem. (Pratiwi et al, 2019; Eriany, 2014; Sunirah et al, 2017)

But this study is not in line with research conducted by Demissie, Tebeje, Tesfaye (2014) which was conducted in Ethiopia where the study respondents were dominated by respondents who had the desire to have children. The main reason respondents plan to have children is because they want to have a family successor, so they choose to plan a pregnancy by still taking ARV adherence and following the 
PMTCT program so that their child is expected to be free from the HIV virus. The inequality of the results of this study is because the research location is different from that of the study. In addition, in developed countries the risk of children acquiring HIV from mothers can be reduced to less than $2 \%$ because of the availability of PMTCT interventions with optimal services. However, in developing countries or poor countries, with minimal access to interventions, the risk of transmission still ranges between $25 \%$ and 45\% (Ministry of Health, 2011).

\section{Conclusion}

The conclusions drawn from the finding of this study are as follows:

1. Based on the research results it is known that $82.5 \%$ of respondents have good knowledge and $61.3 \%$ of respondents have weak motivation to plan pregnancy

2. The results of the bivariate test using Chi square test obtained a P-val $0.03(<0.05)$. The results showed that there was a significant relationship between the knowledge about PMTCT of WLHA with the Motivation to Plan Pregnancy in Peer Support Groups in Bandung.

\section{Recommendation}

Health workers need to improve their ability to collaborate with peer support groups as a means of providing education so that WLHA knowledge about PMTCT can be increased and the number of WLHA pregnancies and the number of Children with HIV/AIDS does not increase. In addition, promotion of the availability of peer support groups needs to be further improved to increase the range of variations in membership characteristics.

\section{References}

Bandung Dinas Kesehatan Kota (2018). Profil Kesehatan Kota Bandung. Bandung: Dinas Kesehatan Kota Bandung. Retrieved from www.dinkes.bandung.go.id

Cunningham, F.G., Levono, K.J., (2010). Obstetri Williams (2nd ed.). Jakarta: EGC.

UNAIDS. (2017). UNAIDS data 2017. UNAID.

Demissie, D., Tebeje, B., \& Tesfaye, T. (2014). Fertility Desire and Associated Factors Among People Living with HIV Attending Antiretroviral Therapy Clinic in Ethiopia. BMC Pregnancy Childbirth, 14(1), 382-291. Retrieved Maret 2020

Eriany, P., Hernawati, L.,\& Goeritno, H. (2014). Studi Deskriptif Mengenai Faktor-Faktor Yang Mempengaruhi Motivasi Mengikuti Kegiatan Bimbingan Belajar Pada Siswa SMP di Semarang. Psikodimensia, 13(1),115 130.

Isni, K., Shaluhiyah, Z., \& Cahyo, K. (2017, Agustus). Pengetahuan Ibu HIV Mempengaruhi Perilaku Pencegahan Penularan HIV/AIDS dari Ibu ke Bayi di Provinsi Jawa Tengah. Jurnal Promosi KEsehatan Indonesia, 12(2).

KemenKes, R. (2011). Pedoman Nasional Pencegahan Penularan HIV dari Ibu ke Bayi. Jakarta.

Kementerian Kesehatan, R. (2015). Pedoman manajemen program pencegahan penularan HIV dan Sifilis dari ibu ke Anak. Jakarta: Kementerian Kesehatan RI.

Kementerian Kesehatan, R. (2018). Situasi Umum HIV/AIDS dan Tes HIV. Pusat Data dan Infirmasi Kementerian Kesehatan RI.

Notoatmodjo, S. (2014). Ilmu Perilaku Kesehatan. Rineka Cipta.

Nursalam, N. (2016). Metodologi Penelitian Ilmu Keperawatan. Salemba Medika.

Pratiwi, N. B., Shaluhiyah, Z., \& Suryoputro, A. (2019). Perencanaan Memiliki Anak pada Wanita dengan HIV Positif di Kota Semarang. Jurnal Promosi Kesehatan Indonesia, 14(2), 108-121.

Fitriana, D. (2015, November 17). Cultural barriers hamper male involvement in family planning. PKBI| Perkumpulan Keluarga Berencana Indonesia. https://pkbi.or.id/media-clipingscultural-barriers-hamper-maleinvolvement-in-family-planning/

Rahayu, K. D. (2017). Factors Associated with the Use of Contraception in Couple of Peaople Living with HIV/AIDS. Oral Presentation - ICDMIC.

Sowell, R. L., Phillips, K. D., \& Misener, T. R. (1999). HIV Infected Women and Motivation to Add Children to Their Families. Journal of Family Nursing, 5(3), 316-331. doi:10.1177/107484079900500305

Sunirah, Setyowati, \& Rachmawati, I. N. (2017). Gambaran Cara Ibu Hamil Dengan HIV/AIDS dalam Menjalani Kehamilan: Studi Fenomenologi. Journal of Nursing and Health, 1(2), 45-54.

WHO. (2019, November 15). HIV/AIDS. Retrieved from WHO: https://www.who.int/news-room/factsheets/detail/hiv-aids 